Chirurgia (2018) 113: 108-115

No. 1, January - February

Copyright@ Celsius

http://dx.doi.org/10.21614/chirurgia.113.1.108

\title{
Endoscopic Treatment of Benign Esophageal Fistulas Using Fully-covered Metallic Esophageal Stents
}

\author{
Denisa Oprisanescu', Denisa Bucur', Vasile Sandru', Ioan Cristian Nedelcu ${ }^{1,2}$, Madalina Ilie ${ }^{1,2}$, Ruxandra Oprita ${ }^{1,2}$, \\ Gabriel Constantinescu ${ }^{1,2}$
}

${ }^{1}$ Clinical Emergency Hospital, Bucharest, Romania

${ }^{2}$ Carol Davila University of Medicine and Pharmacy, Bucharest, Romania

Corresponding author:

Denisa Oprisanescu, MD

Clinical Emergency Hospital

Gastroenterology Department

Bucharest, Romania

E-mail: denisa.oprisanescu@gmail.com

\section{Rezumat \\ Tratamentul endoscopic al fistulelor esofagiene benigne cu stenturi esofagiene metalice total acoperite}

Fistulele esofagiene nonmaligne sunt o mare problemă medicală, încarcată cu o mare morbiditate, mortalitate şi costuri. Necesitatea de a utiliza metode minim-invazive, eficiente dar şi rapide este stringentă. Montarea stenturilor autoexpandabile total acoperite este o opțiune din ce în ce mai utilizată şi se adresează fistulelor ce apar la o distanță mai mare de 2-3 cm de gura Killian şi până la joncțiunea esogastrică. Scopul a la long al procedurii este închiderea fistulei şi vindecarea pacientului. Un obiectiv secundar este împiedicarea apariției complicațiilor generate de utilizarea pe durată lungă a stenturilor şi anume perforația digestivă şi stenoza de lumen. Scopul studiului este evaluarea eficientei utilizarii stenturilor metalice autoexpandabile total acoperite in conditiile fistulelor esofagiene nonmaligne. In acest sens, am efectuat un studiu retrospectiv asupra a 21 de pacienți admişi în clinica noastră în perioada ianuarie 2014 - aprilie 2017 pentru fistule esofagiene non-maligne cu intenția de a închide orificiul fistular prin stentare esofagiană. Criteriile de selecție au fost: fistule postoperatorii (gastric sleeve, hernie gastrica transhiatala cu fundoplicatura, chiar şi malignități la care s-a reuşit exereza tumorii), fistule după ingestii de corpi străini, fistule post-traumatice. Au fost incluse şi fistulele apărute pe ambele versante ale anastomozei eso-jejunale (în cazul gastrectomiilor totale).

Rezultate: Stenturile au fost eficiente la $76 \%$ din cazuri determinând închiderea fistulei. La restul pacienților fistula a rămas patentă sau pacienții nu au tolerat stentul metalic necesitând extragerea 
precoce a protezei esofagiene. Un număr de $42 \%$ din pacienți a necesitat repoziționarea protezei şi mai ales schimbarea ei cu una de alte dimensiuni. La 19\% din pacienții la care protezarea a fost cu succes s-a înregistrat stenoza esofagiană pe ulcere induse de stent şi au necesitat restentare de calibrare sau dilatare cu bujii Savary. $22 \%$ dintre pacienți au necesitat drenaj chirurgical transparietal pentru colecții concomitente cu fistula esofagiană. S-au înregistrat 2 decese, necorelate cu procedura de stentare. Pacienții la care nu s-a reuşit închiderea fistulei au fost trimişi la chirurgie toracică cu o stare generală conservată de prezența stentului

Concluzii: Protezarea fistulelor esofagiene benigne este o procedură endoscopică eficientă, cu un succes terapeutic relativ ridicat. Urmărirea strânsă a pacientului şi abilitatea de a repoziționa /schimba stentul este esențială. Stenturile cu design special trebuie să intre în recuzită. Cooperarea strânsă cu chirurgul toracic este obligatorie.

Cuvinte cheie: fistula esofagiană benignă, SEMS, stent esofagian metalic total acoperit

\begin{abstract}
Non-malignant esophageal fistulas have a wide spectrum of clinical and pathological features and it's important to learn to detect and treat them, due to significant morbidity, mortality and costs. The need for minimally invasive, efficient and also quick procedures is imperative. Esophageal stenting using fully-covered expandable stents has become an increasingly preferred option and addresses to fistulas which arise from $2-3 \mathrm{~cm}$ beyond Killian's mouth and up to the gastroesophageal junction. The long-term purpose of the procedure is closure of the fistula and thus healing. A second goal would be avoiding the complications generated by long-term wearing of the stent, such as gastrointestinal perforation and stenosis.

Objectives: This review focuses on the efficacy of fully-covered metallic stents in treating benign esophageal fistulas. To this effect, we performed a retrospective study on 21 patients admitted in our clinic between January 2014 and April 2017 for non-malignant esophageal fistulas. The selection criteria were the following: post-operative fistulas (gastric sleeve, fundoplication for transhiatal gastric hernia, even malignancies for which surgical tumor removal was performed), foreign body acquired fistulas, post-traumatic fistulas. Esophago-jejunal anastomotic fistulas were also included in the study (following complete gastrectomy).

Results: The efficacy of esophageal stenting was proven in $76 \%$ of the cases, resulting in fistula closure. The rest of the patients either didn't achieve fistula closure or couldn't tolerate the stent, calling for early removal of the prosthesis. Reintervention procedures such as stent repositioning or stent replacement (with higher diameter) were carried out in $42 \%$ of the cases. A percentage of $19 \%$ of the patients who achieved fistula closure developed esophageal stricture on stent-induced ulcers and needed recalibration stenting or esophageal Savary dilation. $22 \%$ of the cases needed surgical drainage for infected collections developed simultaneously. We recorded 2 deaths, unrelated to the stenting procedure. Patients who didn't acquire fistula closure were referred to thoracic surgery in good physical condition.

Conclusions: Fully-covered metallic esophageal stents can be successfully used to treat benign esophageal fistulas. Follow-up of the patient in order to see if stent repositioning or replacement is needed is crucial. Special design esophageal stents are highly recommended and must not lack. Close cooperation with thoracic surgery is indispensable.
\end{abstract}

Key words: benign esophageal fistula, SEMS, fully covered esophageal stent 


\section{Introduction}

Esophageal fistulas are defined by a pathological communication between the esophageal lumen and other mediastinal or abdominal structures, thus encompassing a pressing medical matter. Patients can present for feeding and breathing disorders, intractable cough, repeated respiratory infections, fever.

Although benign esophageal fistulas have not been described in such large numbers as malignant fistulas, they are of vast importance due to their affiliation to high rates of morbidity and mortality. The great majority of non-malignant esophageal fistulas in adults are acquired: postoperative fistulas (digestive/bronchopulmonary surgery, bariatric surgery), post-traumatic fistulas, foreign body acquired fistulas. Over the last three decades the aetiology of benign acquired EFs has changed. Iatrogenic and traumatic causes have now superseded infection, formerly the predominant aetiology of acquired fistulas. Owing to their nonspecific symptoms and rarity, however, benign esophageal fistulas may be present for a long time without being diagnosed and properly treated, resulting in significant morbidity and death (1).

Nowadays we confront with the necessity of using less-invasive, efficient procedures which minimize the recovery period and the complications implied by surgical approach. Due to its efficacy and time-sparing advantage, endoscopic placement of fully-covered expandable stents has become an increasingly preferred option.

\section{Esophageal Stenting in Benign Esophageal Conditions}

Originally, esophageal stents were made of stiff plastic fabric, their main purpose being palliation of malignant dysphagia. However, these rigid plastic prostheses have been associated with high complication and morbidity rates $(2,3)$. Currently, esophageal stents are made from metal alloy compounds and durable polymers and are used for the treatment of a variety of both benign and malignant esophageal conditions. Benign conditions include refractory strictures, esophageal fistulas, iatrogenic perforations and leaks. Along with the development of selfexpanding plastic stents (SEPS) and selfexpanding metal stents (SEMS), stent placement for esophageal pathologies can be safe and cost-effective $(3,4)$. According to published studies, SEPS appear to be safe for use with minimal tissue trauma in alleviating symptoms caused by benign esophageal conditions such as esophageal fistulas, but the use of these stents is limited by migration and poor long-term outcomes. Although SEMS are very effective for the palliation of malignant pathologies, several limitations have precluded routine use of these stents. Tissue embedment after stent placement renders removal of the stents very difficult and often traumatic. Also, multiple studies of conventional uncovered SEMS have reported significant complications, such as bleeding, fistulas, embedment and erosion (5-7). However, recent studies have shown that fully covered SEMS may be able to overcome the problems of partially or completely uncovered SEMS. Many of the problems associated with uncovered or partially covered SEMS may be solved by the use of fully covered SEMS and given the complications and poor long-term outcomes associated with SEPS, they represent an attractive alternative for treatment of benign esophageal conditions such as fistulas $(2,8,9)$.

\section{Materials and Methods}

The aim of the study was to evaluate the efficacy of self-expanding metallic stents in the treatment of benign esophageal fistulas, the objective being closure of the defect.

We conducted a retrospective study on 21 patients (Table 1) admitted in our clinic between january 2014 - april 2017 for benign esophageal fistulas, with the intent of closing the anastomotic leak using esophageal stenting. We considered the following data from the start:

- Identification data of the patients, including phone number; 
Table 1. Patients table

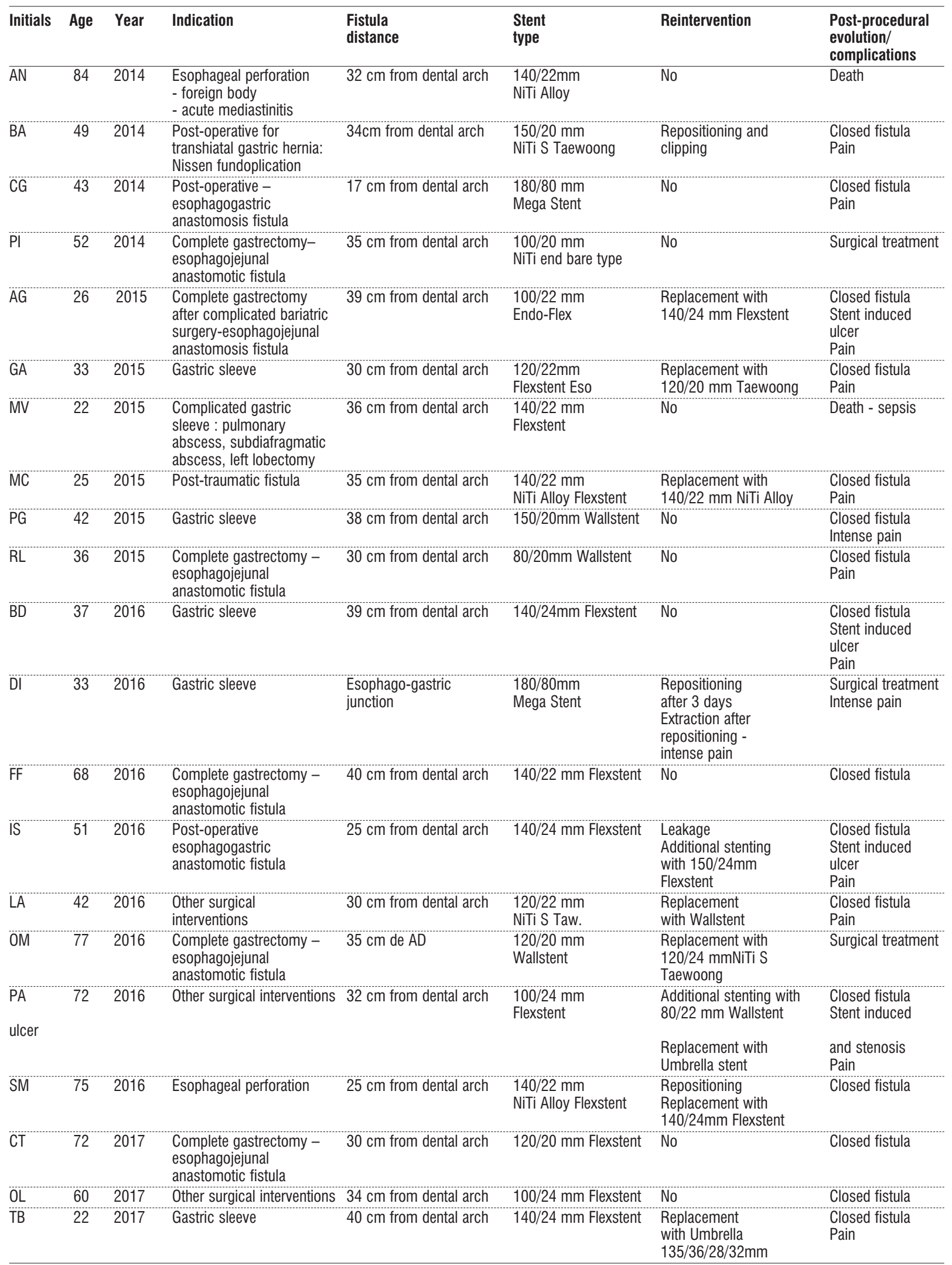


- Symptoms;

- The anatomical distance at which we identified the fistulas during the endoscopic examination;

- The type of stent inserted (manufacturer and dimensions);

- Direct evaluation or through medical records at 1-3-6 months interval.

Inclusion and exclusion criteria for the patients in the study are described below in Table 2.

SEMS are cylindrical in shape and are devised in a number of diameters and lengths to suit the application in question. The types of stents which we used were fully covered SEMS $10-15 \mathrm{~cm}$ long, $20-24 \mathrm{~mm}$ in diameter, heads 26-28 mm with double-tulip ends, double-cup ends and proximal cup-distal umbrella ends. Manufacturers were as follows: Endo-Flex GmbH, NiTi S Taewoong Medical (cervical stent, fully covered esophageal stent, Mega Stent). Boston Microvasive S - Wallstent, Flexstent, Micro-Tech - Cardia Umbrella Stent.

The placement of SEMS regarding esophageal fistulas has the following steps:

1. Identification of defective area;

2. Marking the defective area with submucosal contrast injections;

3. Placement of guidewire into the stomach under fluoroscopic guidance;

4. Placement of fully-covered metallic stent over the guidewire;

5. Stent deployment under fluoroscopic guidance.

After placement of the prosthesis and before resuming oral feeding, a chest x-ray and contrast-enhanced esophagography are performed to rule out perforation and to ensure the right position of the stent. Patients are given nutritional instructions in order to avoid food impactation within the lumen of the stent and are usually allowed oral feeding 12 hours after the insertion of the stent. Diet is recommended to be started with liquids and semi-solid food and high fiber meals are to be avoided. Drinking during and between meals is also recommended and patients are advised to eat and sleep when possible at a 30 degree angle.

Given the risk of post-interventional pain, we always started with $20-24 \mathrm{~mm}$ diameters and $10-15 \mathrm{~cm}$ lengths. The evolution was monitored by contrast-enhanced examination and chest x-ray 24 hours after the stent insertion. Patients were reevaluated whenever there were signs of stent displacement of loss of initial contention. The choice of repositioning or switching to another stent with a different geometry, including Mega-Stent/ Umbrella Stent (Figs. 1, 2) was indicated when signs of active fistula were still present. Depending on the particular anatomical requirements, in some cases we ordered custom-made fullycovered Umbrella stents with specific lengths and diameters (as shown in Fig. 3), in order to ensure high positional stability and prevent migration.

\section{Results}

The age of presentation within the study group ranged from 22 to 84 years old, with a mean of 48 years old. The stenting indications were covering the benign esophageal fistulas of various etiologies, described below in Fig. 4 .

Table 2. Patient inclusion and exclusion criteria

\begin{tabular}{ll}
\hline Patient inclusion criteria & Patient exclusion criteria \\
\hline $\begin{array}{l}\text { The presence of an anastomotic leak at a distance bigger } \\
\text { than 2-3 cm beyond the pharyngo-esophageal junction }\end{array}$ & $\begin{array}{l}\text { The presence of an anastomotic leak at 2-3 cm above the } \\
\text { pharyngo-esophageal junction (including intubation fistulas) }\end{array}$ \\
\hline $\begin{array}{l}\text { Documentation of the fistula using computer tomography, } \\
\text { contrast-enhaced esophagography or endoscopic fistuloscopy } \\
\text { using GIF-N180 endoscope }\end{array}$ & Malignant ethiology of the fistula \\
\hline $\begin{array}{l}\text { Previous thoracic surgery evaluation confirming the indication } \\
\text { of stent insertion }\end{array}$ & Uncertainty of benign/malignant differential diagnosis \\
\hline No evidence of local malignancy & \\
\hline
\end{tabular}




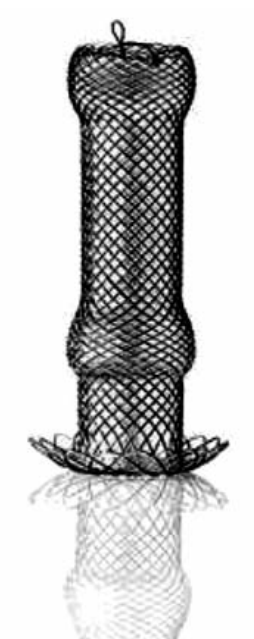

Figure 1. Fully covered self expanding metal esophageal Umbrella stent

Figure 3. Design of a custom-made, fully-covered Umbrella Stent $140 \mathrm{~mm}$ length 36/28/32mm diameters

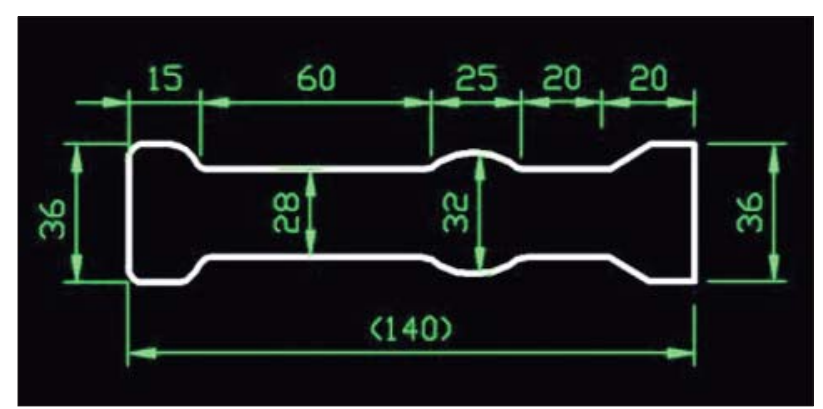

\section{STENTING INDICATIONS}

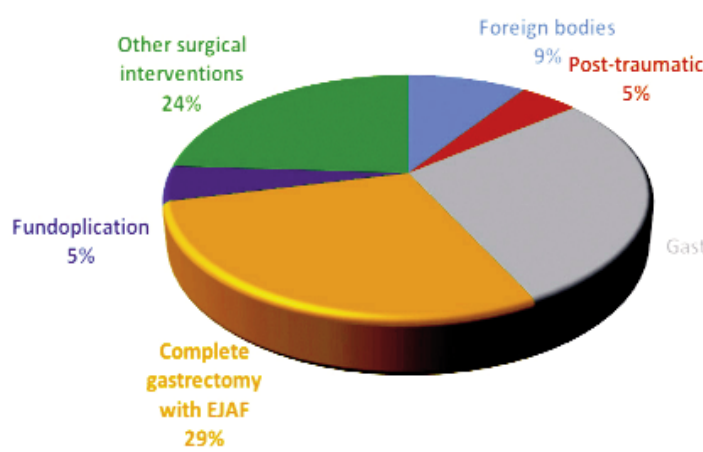

\section{Procedure Efficacy}

The efficacy of esophageal stenting was proven in $76 \%$ of the cases, resulting in fistula closure. The rest of the patients either didn't achieve fistula closure or couldn't tolerate the stent, calling for early removal of the prosthesis. Regarding the cases where fistula closure was not achieved from the first attempt, an additional stent with a different geometry (more compressive, 2-4 mm wider) was inserted, and after that, in the event of failure, we either placed and Umbrella Stent (2 cases), or in case of intrathoracic fistulas, we referred the patients to thoracic surgery in good physical condition. We recorded 2 deaths, unrelated to the stenting procedure (determined by the chronic or acute illness complications). 
Reintervention procedures such as stent repositioning or stent replacement (with higher diameter) were carried out in $42 \%$ of the cases, due to early migration of the stent within the first 2-3 weeks post-insertion. All cases for which Umbrella stent or Mega Stent were placed after the conventional stent had a positive outcome. In one case Mega Stent was the first choice, but the stent generated intense pain requiring ver early extraction.

Our clinic experience regarding various types of stents is found in Table 3.

\section{Complications}

Post-interventional thoracic pain was incriminated in $62 \%$ of the cases, requiring common analgesics or minor opiates. Two of the cases developed intense pain, thus prolonging the analgesic treatment for a longer period of time. One case required stent repositioning after 3 days and after that early extraction due to intense pain which could not be tolerated. The patient was transferred to the thoracic surgery department.

Early migration of the stent was found in $42 \%$ of the cases, requiring repositioning or stent replacement.

In $22 \%$ of the cases, surgical drainage was needed for infected collections developed simultaneously with the esophageal fistula.

$19 \%$ of the patients who achieved fistula closure developed esophageal stricture on stent-induced ulcers and needed recalibration stenting or esophageal Savary dilation (see Table 4).

\section{Discussions}

Despite the widespread use of SEMS nowadays, there is still a paucity of reports and limited experience regarding their involvement in nonmalignant esophageal conditions, such as esophageal fistulas. In our experience, fully covered SEMS can be successfully used as a first choice of treatment for benign esophageal fistulas, having achieved fistula closure in a very high percentage of cases $(76 \%)$. Regarding the
Table 3. Fully covered self expanding metal esophageal stents used within January 2014 - April 2017

\begin{tabular}{lc}
\hline Total number of patients & 21 \\
\hline Total number of self expanding metal esophageal stents & 30 \\
\hline Flexstent & 18 \\
\hline BS Microvasive Wallstent & 4 \\
\hline NiTi S Taewoong Medical & 4 \\
\hline Cardia Umbrella Stent & 2 \\
\hline NiTi S Taewoong Medical Mega Stent & 2 \\
\hline
\end{tabular}

Table 4. Complications of esophageal stenting

\begin{tabular}{lc}
\hline Post-interventional thoracic pain & $62 \%$ \\
\hline Post-interventional intense thoracic pain & $9,5 \%$ \\
\hline Stent migration & $42 \%$ \\
\hline Surgically drained collections & $22 \%$ \\
\hline Esophageal stenosis on stent-induced ulcers & $19 \%$ \\
\hline
\end{tabular}

most common complications, $62 \%$ of the patients developed chest pain and $42 \%$ developed stent migration following the procedure. These results are comparable with data from other studies conducted on SEMS placement for treatment of benign esophageal conditions, with success rates varying from $30 \%$ to $90 \%$ and complication rates of $30 \%$ for stent migration (10-12).

All the patients in our study underwent early SEMS treatment with a mean diagnosis delay of 1-2 days which, considering the favorable post-procedural evolution and high rate of fistula closure, further encourages early stent treatment. Other studies also show that early stent insertion enables very good outcome with minimal mortality and morbidity and no need for operative treatment $(9,13)$.

Regarding the post-interventional aspects, follow-up of the patient is crucial, in order to detect as soon as possible if additional measures such as stent repositioning or replacement need to be taken. Close cooperation between the gastroenterologist, thoracic surgeon and radiologist is also required for the appropriate management of patients.

\section{Conclusion}

In conclusion, primary endoscopic treatment 
of benign esophageal fistulas using fully covered SEMS was associated with a high rate of long-term improvement and fistula closure in the study that we conducted. Endoscopic closure techniques represent a promising alternative to surgical treatment and will improve significantly in time, along with the continuous development of new endoscopic devices. Nevertheless, we consider that there is a need for further, larger, prospective studies in order to assess these procedures, compare the clinical efficacy of different endoscopic techniques and evaluate the outcomes of both endoscopic and surgical management of non-malignant esophageal fistulas.

\section{References}

1. Ahn JY, Jung HY, Choi JY, Kim MY, Lee JH, Choi KS, et al. Benign bronchoesophageal fistula in adults: endoscopic closure as primary treatment. Gut Liver. 2010;4(4):508-13. doi: 10.5009/gnl. 2010.4.4.508. Epub 2010 Dec 17.

2. Hindy P, Hong J, Lam-Tsai Y, Gress F. A comprehensive review of esophageal stents. Gastroenterol Hepatol (N Y). 2012;8(8):526-34.

3. Dai YY, Gretschel S, Dudeck 0, Rau B, Schlag PM, Hünerbein M. Treatment of oesophageal anastomotic leaks by temporary stenting with self-expanding plastic stents. Br J Surg. 2009;96(8):887-91. doi: $10.1002 /$ bjs.6648.

4. Wadhwa RP, Kozarek RA, France RE, Brandabur JJ, Gluck M, Low $\mathrm{DE}$, et al. Use of self-expandable metallic stents in benign $\mathrm{Gl}$ diseases. Gastrointest Endosc. 2003;58(2):207-12.
5. Spaander MC, Baron TH, Siersema PD, Fuccio L, Schumacher B, Escorsell À, et al. Esophageal stenting for benign and malignant disease: European Society of Gastrointestinal Endoscopy (ESGE) Clinical Guideline. Endoscopy. 2016;48(10):939-48. doi: 10.1055/ s-0042-114210. Epub 2016 Sep 14.

6. Wong RF, Adler DG, Hilden K, Fang JC. Retrievable esophageal stents for benign indications. Dig Dis Sci. 2008;53(2):322-9. Epub 2007 Jun 28.

7. Babor R, Talbot M, Tyndal A. Treatment of upper gastrointestinal leaks with a removable, covered, self-expanding metallic stent. Surg Laparosc Endosc Percutan Tech. 2009;19(1):e1-4. doi: 10.1097/SLE.0b013e318196c706.

8. Evrard S, Le Moine 0, Lazaraki G, Dormann A, El Nakadi I, Devière J. Self-expanding plastic stents for benign esophageal lesions. Gastrointest Endosc. 2004;60(6):894-900.

9. Salminen P, Gullichsen R, Laine S. Use of self-expandable metal stents for the treatment of esophageal perforations and anastomotic leaks. Surg Endosc. 2009;23(7):1526-30. doi: 10.1007/s00464-0090432-4. Epub 2009 Mar 20.

10. Eloubeidi MA, Talreja JP, Lopes TL, Al-Awabdy BS, Shami VM, Kahaleh M. Success and complications associated with placement of fully covered removable self-expandable metal stents for benign esophageal diseases (with videos). Gastrointest Endosc. 2011;73(4):673-81. doi: 10.1016/j.gie.2010.11.014. Epub 2011 Jan 26.

11. Buscaglia JM, Ho S, Sethi A, Dimaio CJ, Nagula S, Stavropoulos SN, et al. Fully covered self-expandable metal stents for benign esophageal disease: a multicenter retrospective case series of 31 patients. Gastrointest Endosc. 2011;74(1):207-11. doi: 10.1016/ j.gie.2011.02.024. Epub 2011 May 6.

12. Gianfranco D, Parag D, Silvana P, Bernard D, Michele V, Didier M, et al. Endoscopic placement of fully covered self expanding metal stents for management of post-operative foregut leaks. J Minim Access Surg. 2012;8(4):118-24. doi: 10.4103/0972-9941.103109.

13. Fischer A, Thomusch O, Benz S, von Dobschuetz E, Baier P, Hopt UT. Nonoperative treatment of 15 benign esophageal perforations with self-expandable covered metal stents. Ann Thorac Surg. 2006; 81(2):467-72. 